\title{
Sex differences in the development of vascular and renal lesions in mice with a simultaneous deficiency of Apoe and the integrin chain Itga8
}

Ines Marek', Maurizio Canu', Nada Cordasic ${ }^{2}$, Manfred Rauh ${ }^{1}$, Gudrun Volkert ${ }^{1}$, Fabian B. Fahlbusch', Wolfgang Rascher ${ }^{1}$, Karl F. Hilgers², Andrea Hartner ${ }^{1 *}$ and Carlos Menendez-Castro ${ }^{1}$

\begin{abstract}
Background: Apoe-deficient $\left(\mathrm{Apoe}^{-/-}\right)$mice develop progressive atherosclerotic lesions with age but no severe renal pathology in the absence of additional challenges. We recently described accelerated atherosclerosis as well as marked renal injury in Apoe ${ }^{-/-}$mice deficient in the mesenchymal integrin chain $\operatorname{ltga8}\left(\operatorname{Itga8^{-/-}}\right)$. Here, we used this $A p o e^{-/-}$, Itga $8^{-/-}$mouse model to investigate the sex differences in the development of atherosclerosis and concomitant renal injury. We hypothesized that aging female mice are protected from vascular and renal damage in this mouse model.
\end{abstract}

Methods: $\mathrm{Apoe}^{-/-}$mice were backcrossed with $1 \mathrm{tga8^{-/ }}$ mice. Mice were kept on a normal diet. At the age of 12 months, the aortae and kidneys of male and female $A p o e^{-/-} \operatorname{tga8^{+/+}}$ mice or Apoe ${ }^{-/-} \operatorname{ltga8^{-/-}}$ mice were studied. En face preparations of the aorta were stained with Sudan IV (lipid deposition) or von Kossa (calcification). In kidney tissue, immunostaining for collagen IV, CD3, F4/80, and PCNA and real-time PCR analyses for II6, Vegfa, Col1a1 (collagen I), and Ssp1 (secreted phosphoprotein 1, synonym osteopontin) as well as ER stress markers were performed.

Results: When compared to male mice, $A p o e^{-/-} \mid \operatorname{tga}^{+/+}$female mice had a lower body weight, equal serum cholesterol levels, and lower triglyceride levels. However, female mice had increased aortic lipid deposition and more aortic calcifications than males. Male Apoe ${ }^{-/-}$mice with the additional deficiency of Itga8 developed increased serum urea, glomerulosclerosis, renal immune cell infiltration, and reduced glomerular cell proliferation. In females of the same genotype, these renal changes were less pronounced and were accompanied by lower expression of interleukin- 6 and collagen I, while osteopontin expression was higher and markers of ER stress were not different.

Conclusions: In this model of atherosclerosis, the female sex is a risk factor to develop more severe atherosclerotic lesions, even though serum fat levels are higher in males. In contrast, female mice are protected from renal damage, which is accompanied by attenuated inflammation and matrix deposition. Thus, sex affects vascular and renal injury in a differential manner.

Keywords: a8 integrin, Itga8, Atherosclerotic lesions, Renal lesions, Knockout mice, Sex differences, Apolipoprotein E, Vascular remodeling

\footnotetext{
* Correspondence: andrea.hartner@uk-erlangen.de

${ }^{1}$ Department of Pediatrics and Adolescent Medicine, University Hospital of

Erlangen-Nuernberg, Loschgestrasse 15, 91054 Erlangen, Germany

Full list of author information is available at the end of the article
} 


\section{Background}

Mice with a deficiency of Apoe develop hypercholesterolemia followed by progressive atherosclerotic lesions $[1,2]$. Hypercholesterolemia is a risk factor for renal damage [3, 4], although Apoe-deficient mice without an atherogenic diet do not commonly develop overt renal pathologies [5]. We, therefore, crossed Apoe-deficient mice with mice which had a deletion of the Itga8 (alpha8 integrin) gene, which have reduced nephron numbers and are prone to develop renal disease when challenged [6]. Alpha8 integrin is a matrix receptor mainly found on mesenchymal cells like vascular smooth muscle cells and renal mesangial cells [7]. It is known to exert protective effects for the vasculature most likely by inhibiting smooth muscle cell migration in vascular injury $[5,8,9]$. Moreover, the expression of Itga8 in renal mesangial cells supports their adhesion and thereby confers structural integrity of the glomerular tuft [9]. As a consequence, mice with a deletion of Itga8 do not develop overt glomerular injury per se, but are prone to develop glomerulosclerosis when challenged. Little is known so far regarding sex-specific differences in integrin signaling; however, some studies suggest that there is an effect of sex $[10,11]$. In a previous study, we investigated the vascular and renal phenotype of male mice with a concomitant deficiency of Apoe and Itga8. These mice developed more severe atherosclerotic lesions than mice only deficient in Apoe. Moreover, renal injury became overt in male mice with a concomitant deficiency of Apoe and Itga8 [5].

Sex has an impact on the development and progression of vascular and renal disease [12-14]. A number of experimental studies in Apoe-deficient mice detected sex differences in the development and progression of vascular and renal disease [15]. In most cases, the male sex was a risk factor to develop more severe cardiovascular and renal damage [16-19]. On the other hand, studies exist which found females more seriously affected by vascular lesions [20], or alternatively, no significant differences between vascular lesion sizes of males and females were observed [21]. In the present study, we have compared vascular and renal changes in male and female mice with a deletion for both Apoe and Itga8. We utilized the deficiency of Itga8 to increase the susceptibility of the Apoe-deficient mice to develop glomerulosclerosis. As the progression of glomerulosclerosis is critically influenced by sex hormones [22-24], we hypothesized that female mice are protected from the increased risk for glomerulosclerosis seen in male mice of our experimental atherosclerosis model.

\section{Methods}

\section{Animal procedures}

Itga8-deficient mice $\left(\right.$ Itga $8^{-/-}$, gift from Dr. Ulrich Muller, Scripps Institute, La Jolla, USA) on a mixed genetic background (C57BL/6x129Sv) were crossed with Apoe-deficient mice $\left(A p o e^{-/-}\right)$, which are prone to develop atherosclerotic lesions (Charles River, Sulzfeld, Germany). Animals were kept on a standard rodent maintenance diet (\#1320, Altromin, Lage, Germany) containing $4 \%$ fat (http://www.altromin.com/fileadmin/ downloads/specs/standard/1320.pdf) with free access to tap water in a room maintained at $22 \pm 2{ }^{\circ} \mathrm{C}$ with a 12 -h dark/light cycle. All procedures performed on animals were approved by the local government authorities (Regierung von Mittelfranken, AZ No. 621-2531.31-10/ 02) and were done in compliance with the DIRECTIVE 2010/63/EU of the European Parliament. Male and female litters of the genotypes Apoe $^{-/-} \operatorname{Itga8}^{+/+}(n=11$ for males and $n=12$ for females) and Apoe $^{-1-} \operatorname{Itgas}^{-/-}(n=$ 12 for males and $n=18$ for females) were used to perform histological analyses at the age of 1 year. For gene expression analyses, additional animals were used to prepare RNA from aortae and kidneys $\left(\right.$ Apoe $^{-/-} \operatorname{Itga8}^{+/+}: n$ $=6$ for males, $n=5$ for females and Apoe $^{-/-}$Itga8 $^{-/-}: n$ $=7$ for males and $n=7$ for females). Additional control groups for the evaluation of the effects of an Itga8 deficiency only were $A p o e^{+/+} \operatorname{Itgas}^{+/+}(n=11$ for males and $n=12$ for females) and $A$ poe $^{+/+}$Itgas $^{-/-}$at the age of 1 year ( $n=14$ for males and $n=11$ for females). The time point of sacrifice was chosen based on pilot studies and published data describing the time course of lesion development in this mouse model under standard rodent chow [25]. We also sacrificed some animals at the age of 7 and of 9 months ( $n=6$ per group) to follow the progress of lesion development. Mice were sacrificed between 8:00 in the morning and noon without prior fasting. Blood samples were obtained at sacrifice after isoflurane anesthesia. For vascular analyses, adventitial tissue was removed from the aorta and the distal part of the brachiocephalic trunk. The brachiocephalic trunk was used for preparing paraffin sections. The aorta was prepared en face as described [26]. For kidney analyses, tissue samples were prepared for histology and immunohistochemistry as described [27, 28].

\section{Serum analyses}

Total plasma cholesterol, high-density lipoprotein (HDL), cholesterol, triglycerides, creatinine, and urea were measured using an automatic analyzer, Integra 800 (Roche Diagnostics, Mannheim, Germany). Serum values of low-density lipoprotein (LDL) were calculated using the Friedewald formula [29]. The concentration of testosterone was measured in mouse serum by using liquid chromatography-tandem mass spectrometry (LC-MS/ MS) as described in [30]. The steroid testosterone was measured by a modified online SPE-HPLC-MS/MS combined with atmospheric pressure chemical ionization in the positive ion mode. 


\section{En face preparations of the aorta}

The aorta was fixed with $4 \%$ paraformaldehyde and opened longitudinally after spanning the aortic arch to the iliac bifurcation as described before [26]. Sudan IV staining was performed to detect lipid deposition of atherosclerotic plaques. Von Kossa staining was used to detect calcifications. Native and Sudan IV-stained as well as native and von Kossa-stained aortic preparations were photographed, and the image analysis software MetaVue (Molecular Devices, Sunnyvale, CA, USA) was used to quantify atherosclerotic lesions as a percentage of total aortic surface area. Lipid deposition and calcification were quantified in the aortic arch and the descending aorta separately.

\section{Vascular histology}

The distal part of the brachiocephalic trunk was fixed in $4 \%$ paraformaldehyde and embedded in paraffin. Twomicrometer cross sections of the brachiocephalic trunk were stained with PAS and von Kossa to confirm calcifications.

\section{Immunohistochemistry}

For immunohistochemical staining, kidneys were fixed in methyl Carnoy's solution and embedded in paraffin. Two-micrometer sections were stained as described below. Sections were blocked with $3 \% \mathrm{H}_{2} \mathrm{O}_{2}$. Primary antibodies were incubated overnight at the following dilutions: proliferating cell nuclear antigen (PCNA) for proliferating cells (M0879; DAKO) 1:50, F4/80 for macrophages (LMU8949; Linaris, Dossenheim, Germany) 1:50, CD3 for T cells (I7A2; BioLegend, Fell, Germany) 1:300, collagen IV (Southern Biotechnology, Birmingham, AL, USA) 1:500, osteopontin (OPN; sc-21742, Santa Cruz Biotechnology, Heidelberg, Germany) 1:50. For staining with PCNA and osteopontin, a mouse-onmouse kit was used (M.O.M. Kit, Vector, Burlingame, CA, USA). Appropriate secondary antibodies (Vector) were diluted 1:500, before avidin D peroxidase (Vector) was applied at a dilution of 1:2000. Finally, DAB (Vector) was added, and sections were counterstained with hematoxylin and covered with entellan.

To analyze differences in glomerular proliferation, stained and unstained nuclei were counted and proliferation was expressed as a percentage of positive nuclei/ glomerulus. CD3-positive cells ( $\mathrm{T}$ cells) and F4/80-positive cells (macrophages) were counted in five nonoverlapping medium-power cortical views and presented as positive cells/cortical view. Glomerular collagen IV expression was quantified in 20 glomeruli/renal section, as a ratio of stained area/total area of glomerular cross sections, using MetaVue software.

\section{Isolation of mRNA and real-time PCR}

For expression analyses, kidneys and aortae were taken out and immediately snap frozen on liquid nitrogen and stored at $-80{ }^{\circ} \mathrm{C}$. Aortic or kidney tissue (1-10 mg) was homogenized in 300-500 $\mu \mathrm{l}$ RLT buffer reagent (Qiagen, Hilden, Germany) with an Ultraturrax for $30 \mathrm{~s}$, and total RNA was extracted with RNeasy ${ }^{\circ}$ Mini columns (Qiagen) or RNeasy Fibrous Mini Kit (Qiagen) according to the manufacturer's instructions including RNase-free DNase I treatment on the columns of the RNeasy Mini Kit (Qiagen). RNA concentration was quantified using a NanoDrop ND-1000 spectrophotometer (Thermo Fisher Scientific, Waltham, MA, USA) by measuring the absorbance at $260 \mathrm{~nm}$. Purity of RNA was checked via the A260/A280 nm ratio. TaqMan reverse transcription reagents (Applied Biosystems, Weiterstadt, Germany) with random hexamers as primers were used to obtain firststrand complementary DNA (cDNA). Final concentrations of the reverse transcription master mix were $1 \times$ TaqMan RT buffer, $5.5 \mathrm{mM} \mathrm{MgCl}, 500 \mu \mathrm{M}$ dNTP mix, $2.5 \mu \mathrm{M}$ random hexamers, $0.4 \mathrm{U} / \mu \mathrm{l}$ RNAse inhibitor, and 1.2 $\mathrm{U} / \mu \mathrm{l}$ MultiScribe RT. RNAse-free water (Qiagen) was adjusted to a final volume of $30 \mu \mathrm{l}$ per sample. Final RNA concentration in the reaction mixture was adjusted to $3 \mathrm{ng} / \mu \mathrm{l}$. To test for genomic DNA contamination, reactions without MultiScribe reverse transcriptase were performed as negative controls. Reverse transcription was performed on a thermocycler (TRIO thermoblock, Biometra, Göttingen, Germany) with $10 \mathrm{~min}$ at $25{ }^{\circ} \mathrm{C}$, 45 min at $48{ }^{\circ} \mathrm{C}, 5 \mathrm{~min}$ at $95{ }^{\circ} \mathrm{C}$, and hold at $4{ }^{\circ} \mathrm{C}$. cDNA was stored at $-20{ }^{\circ} \mathrm{C}$. Reverse transcription products were diluted $1: 1$ with $\mathrm{dH}_{2} \mathrm{O}$. Then, real-time PCR was accomplished with a StepOnePlus Real-Time Cycler (Thermo Fisher Scientific) and Fast SYBR Green (Thermo Fisher Scientific) according to the manufacturer's protocol in MicroAmp Fast 96-well reaction plates (Thermo Fisher Scientific). Final concentration of the Fast SYBR Green Master Mix was 1× Fast SYBR Green Master Mix buffer, $200 \mathrm{nM}$ forward primer, $200 \mathrm{nM}$ reverse primer, $2.6 \mu \mathrm{l}$ DNA-free water, and $2 \mu \mathrm{l}$ cDNA per $10 \mu \mathrm{l}$ reaction sample/well. The temperature profile included a holding stage of $20 \mathrm{~s}$ at $95{ }^{\circ} \mathrm{C}$, then $3 \mathrm{~s}$ at $95{ }^{\circ} \mathrm{C}$ followed by $30 \mathrm{~s}$ at $60^{\circ} \mathrm{C}$. The cycle was repeated 40 times. Melting curves were evaluated to check for primer specificity for the PCR product. NTCs were performed. Real-time PCR data were analyzed using the comparative cycle threshold method with normalizing $C_{\mathrm{t}}$ to $R n 18 s$ (18S rRNA). Comparison of Rn18s (18S rRNA), Actb (beta actin), and Gapdh (glyceraldehyde 3phosphate dehydrogenase) as reference genes showed similar results. See Additional file 1 for the primers used for amplification. All samples were run in triplicates of the same reverse transcription replicate. Primer pairs were designed using the Primer Express software 
(PerkinElmer, Foster City, CA, USA) except for Ccl2 (CC-chemokine ligand 2, synonym MCP1) [31] and Eif2ak3 (eukaryotic translation initiation factor 2-alpha kinase 3, synonym PERK) (designed with PubMed primer software).

\section{Analysis of data}

Data are expressed as mean \pm standard error of the mean (SEM), median, and quartile ranges (1.Q/3.Q, IQR). After testing for normality distribution using Shapiro-Wilk's test, we performed either one-way analysis of variance (ANOVA), followed by the Bonferroni post hoc test, or non-parametric Kruskall-Wallis, followed by Dunn's test, where appropriate, to assess the differences between the groups using GraphPad Prism software (Version 7, GraphPad Software Inc, San Diego, CA, USA). For select parameters, two-way ANOVA was performed to assess effects of the factors "sex" and "genotype" as well as their interaction (IBM SPSS Statistics 21, Ehningen, Germany). Results were considered significant at $p<0.05$.

\section{Results}

Apoe-deficient $\left(\right.$ Apoe $\left.^{-/-}\right)$male and female mice, which are prone to develop atherosclerotic lesions with age, were compared for the extent of vascular plaque formation. Apoe-deficient male and female mice with an additional deficiency of Itga8 $\left(\right.$ Apoe $^{-/-}$Itga $\left.8^{-/-}\right)$were compared for the extent of renal injury. Assessment of body weights revealed significantly lower values in female mice of both genotypes $\left(\right.$ Apoe $^{-/-}$Itga $^{+/+}$and Apoe
-/- $\left.\operatorname{Itga} 8^{-/-}\right)$compared to respective males at 1 year of age (Table 1). Relative kidney weights were lower in female mice compared to male mice of the same genotype. A lack in Itga8 $\left(\operatorname{Itga8^{-1-}}\right)$ resulted in reduced kidney weights in males and females (Table 1). As an indirect marker of chronic arterial hypertension, we also assessed relative left ventricular weights, which were not significantly different between all groups (Table 1). Aortic messenger RNA (mRNA) expression of Itga8 was quantified to confirm Itga8 deficiency in double-knockout $\left(\right.$ Apoe $\left.^{-/-} \operatorname{Itga8}^{-/-}\right)$mice (Table 2). Compared with mice, which were wild type for Apoe $\left(\right.$ Apoe $^{+/+}$Itga $^{+/+}$and Apoe $^{+/+}$Itga ${ }^{-/-}$) (Additional file 2), total serum cholesterol as well as LDL cholesterol levels were elevated in Apoe-deficient $\left(\right.$ Apoe $^{-/-}$Itga $^{+/+}$and Apoe $^{-/-}$Itga8 $^{-/-}$) mice (Table 2). The Itga 8 genotype had no influence on serum fat levels within the same Apoe genotype (Table 2 and Additional file 2), and mice with a deficiency of only Itga8 $\left(\right.$ Itga $\left.{ }^{-/-}\right)$did not develop hyperlipidemia (Additional file 2). Serum testosterone levels, which were significantly higher in male mice compared to female mice, did not differ significantly in male mice of the different genotypes (Table 2).

\section{Female Apoe-deficient Apoe $^{-/-}$Itga $8^{+/+}$and Apoe $^{-/-}$Itga8 ${ }^{-1-}$ ) mice develop more severe vascular lesions than males, despite similar serum fat levels}

Total serum cholesterol levels, serum HDL levels, and serum triglycerides were not significantly different between males and females of the genotypes Apoe ${ }^{-/-}$Itga 8

Table 1 Anatomical data

\begin{tabular}{|c|c|c|c|c|c|c|c|c|}
\hline & Genotype & Sex & Mean & SEM & Median & Q1 & Q3 & IQR \\
\hline \multirow[t]{4}{*}{ Body weight (g) } & \multirow[t]{2}{*}{$\mathrm{Apoe}^{-/-} \operatorname{ltga8^{+/+}}$} & Male & 34.4 & 0.8 & 34.1 & 31.7 & 36.0 & 4.3 \\
\hline & & Female & $27.7^{*}$ & 0.9 & 28.3 & 25.5 & 29.0 & 3.5 \\
\hline & \multirow[t]{2}{*}{ Apoe $^{-/-} \operatorname{ltga8^{-/-}}$} & Male & 31.7 & 0.6 & 31.9 & 30.0 & 34.1 & 4.1 \\
\hline & & Female & $28.4^{*}$ & 0.7 & 27.9 & 25.7 & 31.3 & 5.6 \\
\hline \multirow[t]{4}{*}{ Absolute kidney weight (g) } & \multirow[t]{2}{*}{ Apoe $e^{-/-} \operatorname{ltg} a 8^{+/+}$} & Male & 0.42 & 0.01 & 0.44 & 0.38 & 0.47 & 0.0 \\
\hline & & Female & $0.28^{*}$ & 0.01 & 0.27 & 0.26 & 0.30 & 0. \\
\hline & \multirow[t]{2}{*}{ Apoe $e^{-/-} \operatorname{tga} 8^{-/-}$} & Male & $0.29^{\#}$ & 0.01 & 0.27 & 0.26 & 0.33 & 0.0 \\
\hline & & Female & 0.25 & 0.01 & 0.26 & 0.23 & 0.28 & 0. \\
\hline \multirow[t]{4}{*}{ Relative kidney weight (\%) } & \multirow[t]{2}{*}{ Apoe $^{-/-} \operatorname{ltga8^{+/+}}$} & Male & 1.23 & 0.03 & 1.22 & 1.12 & 1.35 & 0.2 \\
\hline & & Female & $1.03^{*}$ & 0.03 & 1.0 & 0.96 & 1.08 & 0.12 \\
\hline & \multirow[t]{2}{*}{ Apoe $^{-/-} \operatorname{ltga8^{-/-}}$} & Male & $0.8^{\#}$ & 0.03 & 0.82 & 0.66 & 0.93 & 0.27 \\
\hline & & Female & $0.76^{\#}$ & 0.03 & 0.74 & 0.63 & 0.87 & 0.2 \\
\hline \multirow[t]{4}{*}{ Relative left ventricular weight (\%) } & \multirow[t]{2}{*}{ Apoe $e^{-/-} \operatorname{ltg} a 8^{+/+}$} & Male & 0.37 & 0.01 & 0.37 & 0.35 & 0.39 & 0. \\
\hline & & Female & 0.33 & 0.01 & 0.32 & 0.31 & 0.35 & 0.0 \\
\hline & \multirow[t]{2}{*}{ Apoe $e^{-1-} \operatorname{ltg} a 8^{-1-}$} & Male & 0.39 & 0.01 & 0.39 & 0.37 & 0.41 & 0. \\
\hline & & Female & 0.36 & 0.01 & 0.35 & 0.32 & 0.38 & 0. \\
\hline
\end{tabular}


Table 2 Cardiovascular and metabolic parameters

\begin{tabular}{|c|c|c|c|c|c|c|c|c|}
\hline & Genotype & Sex & Mean & SEM & Median & Q1 & Q3 & IQR \\
\hline \multirow[t]{4}{*}{ Aortic Itga8 mRNA expression (fold change) } & \multirow[t]{2}{*}{ Apoe ${ }^{-/-} \operatorname{ltg} a 8^{+/+}$} & Male & 0.96 & 0.16 & 0.93 & 0.59 & 1.39 & $\overline{0.80}$ \\
\hline & & Female & 1.00 & 0.26 & 1.05 & 0.35 & 1.62 & 1.27 \\
\hline & \multirow[t]{2}{*}{ Apoe ${ }^{-/-} \operatorname{lga} 8^{-/-}$} & Male & $0.0002^{\#}$ & 0.00 & 0.00 & 0.00 & 0.00 & 0.00 \\
\hline & & Female & $0.05^{\#}$ & 0.05 & 0.00 & 0.00 & 0.00 & 0.00 \\
\hline \multirow[t]{4}{*}{ Plasma triglycerides (mg/dl) } & \multirow[t]{2}{*}{ Apoe $e^{-/-} \operatorname{ltga8^{+/+}}$} & Male & 117 & 16 & 102 & 71.8 & 154 & 82.2 \\
\hline & & Female & 78 & 7 & 77.8 & 56.7 & 102 & 45.3 \\
\hline & \multirow[t]{2}{*}{$\mathrm{Apoe}^{-/-} \operatorname{ltga8^{-/-}}$} & Male & 146 & 24 & 102 & 66.9 & 192 & 125.1 \\
\hline & & Female & 111 & 25 & 81.3 & 58.5 & 114 & 55.5 \\
\hline \multirow[t]{4}{*}{ Plasma total cholesterol (mg/dl) } & \multirow[t]{2}{*}{ Apoe $^{-/-} \operatorname{ltga8^{+/+}}$} & Male & 372 & 40 & 453 & 192 & 522 & 330 \\
\hline & & Female & 406 & 22 & 425 & 345 & 476 & 131 \\
\hline & \multirow[t]{2}{*}{ Apoe ${ }^{-/-} \operatorname{ltga8^{-/-}}$} & Male & 393 & 39 & 402 & 235 & 521 & 286 \\
\hline & & Female & 263 & 28 & 270 & 155 & 363 & 208 \\
\hline \multirow[t]{4}{*}{ Plasma HDL cholesterol [mg/dl] } & \multirow[t]{2}{*}{ Apoe $^{-/-} \operatorname{ltga8^{+/+}}$} & Male & 87 & 9 & 87 & 54 & 106 & 52 \\
\hline & & Female & 96 & 6 & 96 & 83 & 106 & 23 \\
\hline & \multirow[t]{2}{*}{$\mathrm{Apoe}^{-/-} \operatorname{ltga8^{-/-}}$} & Male & 100 & 13 & 74 & 63 & 111 & 48 \\
\hline & & Female & 95 & 7 & 87 & 74 & 101 & 27 \\
\hline \multirow[t]{4}{*}{ Plasma LDL cholesterol (mg/dl) } & \multirow[t]{2}{*}{ Apoe $^{-/-} \operatorname{ltga8^{+/+}}$} & Male & 262 & 33 & 320 & 121 & 379 & 258 \\
\hline & & Female & 295 & 18 & 311 & 251 & 340 & 89 \\
\hline & \multirow[t]{2}{*}{ Apoe $^{-/-}$ltga ${ }^{-/-}$} & Male & 263 & 30 & 296 & 142 & 359 & 217 \\
\hline & & Female & $163^{\# *}$ & 23 & 159 & 67 & 241 & 174 \\
\hline \multirow[t]{4}{*}{ Plasma testosterone (ng/dl) } & \multirow[t]{2}{*}{$\mathrm{Apoe}^{-/-} \operatorname{ltga8^{+/+}}$} & Male & 4 & 2 & 0.63 & 0.32 & 7.48 & 7.16 \\
\hline & & Female & 0.2 & 0.0 & 0.15 & 0.03 & 0.24 & 9.21 \\
\hline & \multirow[t]{2}{*}{ Apoe $^{-/-} \operatorname{ltga8^{-/-}}$} & Male & 11 & 4 & 12.3 & 0.77 & 18.2 & 17.4 \\
\hline & & Female & $0.2^{*}$ & 0.1 & 0.15 & 0.09 & 28.1 & 28.0 \\
\hline \multirow[t]{4}{*}{ Plasma creatinine $(\mu \mathrm{g} / \mathrm{dl})$} & \multirow[t]{2}{*}{$\mathrm{Apoe}^{-/-} \operatorname{ltga8^{+/+}}$} & Male & 52 & 9 & 50 & 20 & 80 & 60 \\
\hline & & Female & 95 & 9 & 100 & 50 & 120 & 70 \\
\hline & \multirow[t]{2}{*}{ Apoe $^{-/-}$ltga ${ }^{-/-}$} & Male & 97 & 8 & 100 & 70 & 130 & 60 \\
\hline & & Female & 140 & 3 & 110 & 80 & 130 & 50 \\
\hline \multirow[t]{4}{*}{ Plaques of aortic arch (\%) } & \multirow[t]{2}{*}{ Apoe $^{-/-} \operatorname{ltga8^{+/+}}$} & Male & 17.7 & 2.34 & 17.1 & 11.7 & 20.6 & 8.9 \\
\hline & & Female & 25.7 & 2.73 & 25.6 & 18.7 & 31.4 & 12.7 \\
\hline & \multirow[t]{2}{*}{ Apoe $^{-/-} \operatorname{ltga8^{-/-}}$} & Male & 26.6 & 2.27 & 25.8 & 20.3 & 34.3 & 14 \\
\hline & & Female & 21.9 & 1.76 & 23.8 & 15.0 & 27.7 & 12.7 \\
\hline \multirow[t]{4}{*}{ Calcification aorta (\%) } & \multirow[t]{2}{*}{ Apoe $^{-/-} \operatorname{ltga8^{+/+}}$} & Male & 0.04 & 0.04 & 0.0 & 0.0 & 0.0 & 0 \\
\hline & & Female & $2.84^{*}$ & 0.51 & 2.66 & 1.58 & 4.39 & 2,81 \\
\hline & Apoe $^{-/-} \mid \operatorname{lga}^{-/-}$ & Male & 0.85 & 0.37 & 0.0 & 0.0 & 1.98 & 1.98 \\
\hline & & Female & 2.76 & 0.63 & 2.56 & 0.0 & 3.79 & 3.79 \\
\hline
\end{tabular}

$\# p<0.05$ vs Itga $8^{+/+}$of the same sex

${ }^{*} p<0.05$ vs male of the same genotype

${ }^{+/+}$and $\mathrm{Apoe}^{-/-}$Itga8 ${ }^{-/-}$(Table 2). Serum LDL levels were somewhat lower in female mice of the $A p o e^{-/-}$ $\operatorname{Itga8^{-/-}}$ genotype. To study the manifestation of atherosclerosis, we assessed the formation of atherosclerotic plaques in the aorta and in the aortic arch. In the aorta, there were significantly more lesions detected in female Apoe $^{-/-}$Itga $^{+/+}$mice, compared to males of the same genotype. In contrast, plaque formation was not different in female and male double-knockout $\left(\mathrm{Apoe}^{-/-}\right.$Itga 8 ${ }^{-/-}$) mice, as male $\mathrm{Apoe}^{-/-} \operatorname{Itga~}^{-/-}$mice showed an increase in atherosclerotic plaque formation in comparison to male $\mathrm{Apoe}^{-/-}$Itga $^{+/+}$(Fig. 1). By two-way ANOVA, there was a significant interaction of sex with genotype regarding aortic plaque formation (see Additional file 3). 
Mice with a deficiency just of Itga8 $\left(\right.$ Apoe $^{+/+}$Itga $\left.8^{-/-}\right)$ did not develop any atherosclerotic plaques (Additional file 4). The calcification of plaques was much more prominent in female Apoe-deficient mice than in males, irrespective of the genotype (Fig. 2 and Additional file 3 ). In atherosclerotic plaques of female mice, osteopontin staining was much more abundant than in plaques of male mice (Additional file 5) and was predominantly detected at sites of calcification. To track the progress of atherosclerosis, we investigated the aortae of mice at an age of 7 and of 9 months, also. At the age of 7 months, lipid deposition was only weak and did not significantly differ between groups (Additional file 6), while at the age of 9 months, female $\mathrm{Apoe}^{-/-}$Itga $^{+/+}$mice displayed an increased atherosclerotic plaque area compared to males of the same genotype (Additional file 6).

\section{Female Apoe-deficient $\left(\mathrm{Apoe}^{-/-}\right.$Itga8 $\left.{ }^{-/-}\right)$mice are} protected from the development of renal injury The deficiency of Itga8 $\left(\operatorname{Itga8^{-/-}}\right)$ resulted in reduced renal mass and increased glomerular perimeters (Table 3 ) in both males and females. An increase in plasma urea as a consequence of the lack of Apoe and Itga8 $\left(\right.$ Apoe $^{-/-}$ $\operatorname{Itg} a 8^{-1-}$ ) was observed in males only (Fig. 3a). A decrease in cell turnover was likewise detected in doubleknockout $\left(\mathrm{Apoe}^{-/-}\right.$Itga $\left.^{-/-}\right)$male mice (Fig. 3b), not in females. Moreover, Itga 8 deficiency $\left(\operatorname{Itga} 8^{-/-}\right)$resulted in more pronounced glomerulosclerosis (Fig. 4) and increased cortical collagen I expression (Fig. 5a) in Apoedeficient $\left(\right.$ Apo $\left.^{-/-}\right)$males as compared to females. Several renal inflammatory markers were induced in double-knockout $\left(\mathrm{Apoe}^{-/-} \operatorname{Itga8^{-/-}}\right)$ male mice. The expression of interleukin-6 (Il6) (Fig. 5b) and T cell infiltration (Fig. 6) was significantly higher in the kidney cortex of male compared to female mice deficient in both Apoe and Itga $8\left(\mathrm{Apoe}^{-/-}\right.$Itga $\left.8^{-/-}\right)$. The expression of the chemokines CXCL-3 ( $\mathrm{Cxcl} 3$, chemokine (C-X-C motif) ligand 3$)$ and $\mathrm{Ccl} 2(\mathrm{Ccl} 2)$ tended to be higher in male mice that were deficient in Apoe and Itga8 $\left(\right.$ Apoe $^{-/-}$Itga $\left.^{-/-}\right)$ when compared to females (Table 3 ). In contrast, renal macrophage infiltration was increased in both doubledeficient $\left(\mathrm{Apoe}^{-/-}\right.$Itga $\left.\mathrm{S}^{-/-}\right)$male and female mice to a a

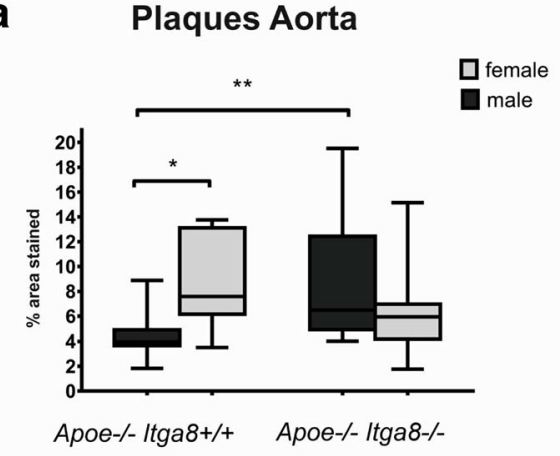

C Brachiocephalic Trunk

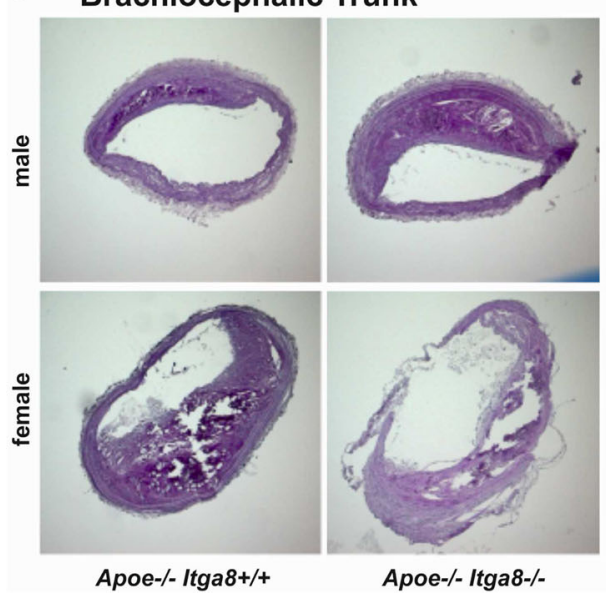

b En face Preparations
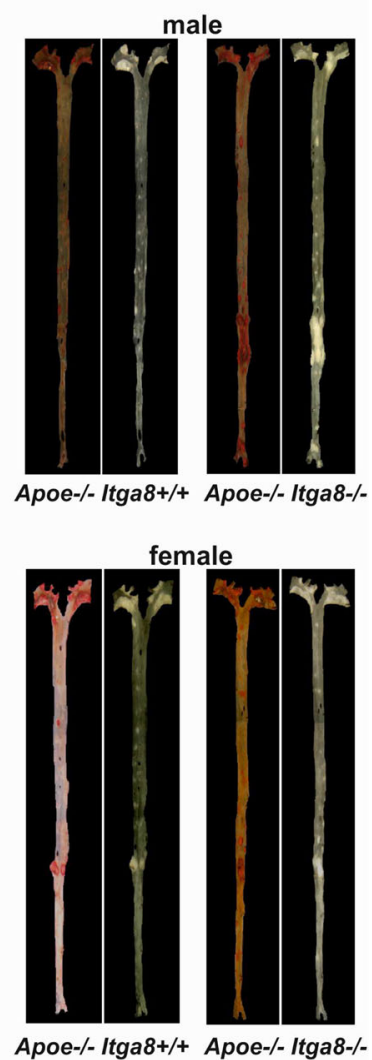

Fig. 1 Atherosclerotic plaque formation. a Evaluation of aortic plaque formation in male and female $A p o e^{-/-} \operatorname{Itga8^{+/+}}$ or $\mathrm{Apoe}^{-/-} \operatorname{Itga8^{-/-}}$ mice. $\mathbf{b}$ Exemplary en face preparations of aortae of male and female Apoe ${ }^{-/-} \operatorname{ltga8^{+/+}}$ or Apoe $e^{-/-} \operatorname{ltga8^{-1-}}$ mice, stained with Sudan IV (left) or unstained

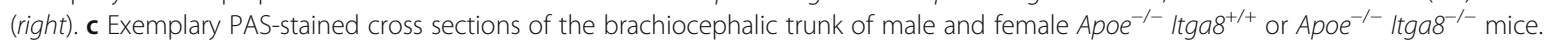
${ }^{*} p<0.05 ;{ }^{* *} p<0.01$ 

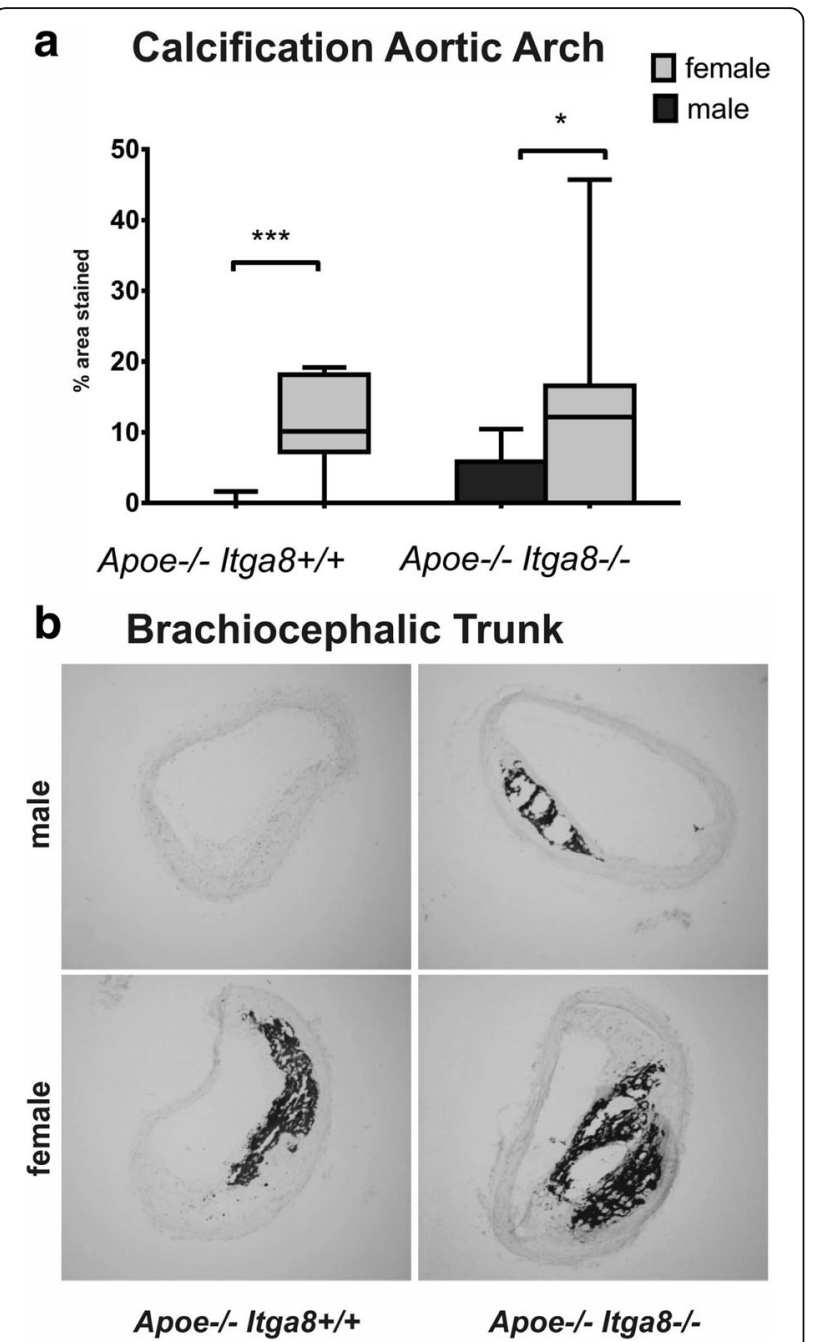

Fig. 2 Vascular calcification. a Evaluation of en face preparations of aortae of male and female $A p o e^{-/-} \operatorname{ltga8^{+/+}}$ or $A p o e^{-/-} \operatorname{Itga8^{-/}}$ mice stained with von Kossa. $\mathbf{b}$ Exemplary von Kossa-stained cross sections of the brachiocephalic trunk of male and female Apoe ${ }^{-/-}$Itga8 ${ }^{+/+}$or $A p o e^{-/-}$Itga $8^{-/-}$mice. ${ }^{*} p<0.05,{ }^{* * *} p<0.001$

similar degree (Table 3). Renal cortical osteopontin expression, on the other hand, was significantly higher in female mice compared to males irrespective of the genotype (Table 3). The localization of renal osteopontin in both males and females of the different genotypes was predominantly found in tubular cells (Additional file 7). Data from a two-way ANOVA of several markers of renal damage are shown in Additional file 3. A reduced level of cell turnover, as seen in male double-deficient $\left(\right.$ Apoe $^{-/-}$Itga $\left.{ }^{-/-}\right)$mice, might indicate increased ER stress of renal cells. Therefore, we investigated renal markers for ER stress, i.e., Eif2ak3, Ddit3 (DNA damageinducible transcript 3) and Hspa5 (heat shock protein family A (hsp70) member 5) expression. However, none of these markers were altered in their expression in the different genotypes and sexes (Table 3). We also evaluated possible differences in renal (mRNA) Vegfa expression levels in male and female mice, which might account for the sex differences in renal injury. Renal (mRNA) Vegfa expression was somewhat higher in female Apoe-deficient mice compared to males of the same genotype $\left(\mathrm{Apoe}^{-/-}\right.$Itga $\left.\mathrm{S}^{+/+}\right)$. There were no sexspecific differences in (mRNA) Vegfa expression levels observed in male and female double-deficient $\left(\right.$ Apoe $^{-/-}$ Itga ${ }^{-1-}$ ) mice (Table 3). At 7 and 9 months of age, glomerular collagen deposition and plasma urea were already increased in male double-deficient $\left(\right.$ Apo $^{-/-}$ Itga ${ }^{-/-}$) mice compared to male Apoe $^{-/-}$Itga $^{+/+}$. This was not observed in female mice (Additional file 6). Renal $\mathrm{T}$ cell infiltration was not yet different between groups at the age of 7 or 9 months (Additional file 6).

\section{Discussion}

From human studies as well as from experimental data, ample evidence exists for sex-dependent differences in the development and progression of cardiovascular disease [32, 33]. The male sex is commonly recognized as an independent risk factor for cardiovascular disease [34]. In male Apoe-deficient mice, previous studies showed that a lack of the vascular integrin Itga 8 is associated with aggravated atherosclerosis and the development of renal injury [5]. The aim of this study was to assess sex-dependent differences in the development of vascular and renal lesions in this model of Apoe and Itga 8 double deficiency.

In summary, we could show that female mice that were deficient in Apoe $\left(\right.$ Apoe $^{-/-}$Itga $\left.^{+/+}\right)$developed more severe atherosclerotic lesions when compared to males of the same genotype. In contrast, glomerular and interstitial lesions in the kidney were attenuated in female mice deficient in Apoe and Itga8 $\left(\right.$ Apoe $^{-/-}$Itga $\left.^{-/-}\right)$ compared to male mice of the same genotype, which indicates that in this model, the female sex is protective for the development of renal injury, but not for the progression of atherosclerosis.

In our experiments, we utilized male and female Apoedeficient litters on a mixed genetic background $\left(\right.$ Apoe $^{-/-}$ Itga $\left.{ }^{+/+}\right)$, which were fed regular chow, and we detected more severe vascular damage in female mice compared to males. In female Apoe-deficient mice, we did not observe an aggravation of atherosclerotic lesions caused by the additional underexpression of Itga8 $\left(\right.$ Apoe $^{-/-}$Itga 8 ${ }^{-1-}$ ), as we saw in male Apoe-Itga 8 double-deficient mice [5]. These previous findings therefore seem to be limited to the male sex. Our observations of more prominent atherosclerotic alterations in female Apoe-deficient mice compared to males are in accordance with the findings of Caligiuri et al., which also showed more severe atherosclerotic lesions in female Apoe-deficient mice in comparison to males [35]. On the other hand, there are 
Table 3 Renal parameters of anatomy, inflammation, and ER stress response

\begin{tabular}{|c|c|c|c|c|c|c|c|c|}
\hline & Genotype & Sex & Mean & SEM & Median & Q1 & Q3 & $\frac{\mathrm{IQR}}{\mathrm{IQR}}$ \\
\hline \multirow[t]{4}{*}{ Glomerular perimeter $(\mu \mathrm{m})$} & \multirow[t]{2}{*}{ Apoe $^{-/-} \operatorname{ltga8^{+/+}}$} & Male & 202 & 2.47 & 202.5 & 197.5 & 208.9 & 11.4 \\
\hline & & Female & 204 & 3.45 & 204.8 & 196.0 & 213.6 & 17.6 \\
\hline & \multirow[t]{2}{*}{ Apoe $^{-1-} \operatorname{ltga8^{-1-}}$} & Male & 225 & 5.19 & 225.6 & 209.2 & 241.2 & 32.0 \\
\hline & & Female & 234 & 6.51 & 234.0 & 220.0 & 247.3 & 27.3 \\
\hline \multirow[t]{4}{*}{ Macrophage infiltration (no. of F4/80-pos. cells/view) } & \multirow[t]{2}{*}{ Apoe $^{-/-} \operatorname{ltga8^{+/+}}$} & Male & 0.92 & 0.52 & 0.0 & 0.0 & 1.0 & 1.0 \\
\hline & & Female & 7.17 & 4.21 & 3.5 & 3.5 & 16.5 & 13.0 \\
\hline & \multirow[t]{2}{*}{$\mathrm{Apoe}^{-/-} \operatorname{ltg} a 8^{-/-}$} & Male & $53.9^{\#}$ & 12.5 & 46.0 & 17.5 & 76.0 & 58.5 \\
\hline & & Female & $53.0^{\#}$ & 10.7 & 38.0 & 23.0 & 79.0 & 56.0 \\
\hline \multirow[t]{4}{*}{ Spp1 mRNA expression (fold change) } & \multirow[t]{2}{*}{ Apoe $^{-/-} \operatorname{ltga8^{+/+}}$} & Male & 0.38 & 0.03 & 0.39 & 0.32 & 0.45 & 0.13 \\
\hline & & Female & $1.00^{*}$ & 0.07 & 1.04 & 0.87 & 1.12 & 0.25 \\
\hline & \multirow[t]{2}{*}{ Apoe $e^{-1-} \mid \operatorname{tga} 8^{-/-}$} & Male & 0.49 & 0.05 & 0.47 & 0.37 & 0.64 & 0.27 \\
\hline & & Female & $1.35^{*}$ & 0.20 & 1.11 & 1.02 & 1.71 & 0.69 \\
\hline \multirow[t]{4}{*}{ Cxc/3 mRNA expression (fold change) } & \multirow[t]{2}{*}{ Apoe $^{-/-} \mid \operatorname{tga} 8^{+/+}$} & Male & 0.75 & 0.18 & 0.66 & 0.39 & 1.22 & 0.83 \\
\hline & & Female & 1.00 & 0.29 & 0.91 & 0.42 & 1.63 & 1.21 \\
\hline & \multirow[t]{2}{*}{$\mathrm{Apoe}^{-/-} \mid \operatorname{tg} a 8^{-/-}$} & Male & $2.61^{\#}$ & 0.68 & 2.25 & 0.75 & 4.34 & 3.59 \\
\hline & & Female & 1.25 & 0.41 & 0.71 & 0.64 & 1.91 & 1.27 \\
\hline \multirow[t]{4}{*}{ Ccl2 mRNA expression (fold change) } & \multirow[t]{2}{*}{ Apoe $^{-/-} \operatorname{ltga8^{+/+}}$} & Male & 0.89 & 0.19 & 0.92 & 0.37 & 1.38 & 1.01 \\
\hline & & Female & 1.00 & 0.34 & 0.77 & 0.32 & 1.79 & 1.47 \\
\hline & \multirow[t]{2}{*}{ Apoe $^{-1-} \operatorname{ltga8^{-1-}}$} & Male & 1.44 & 0.42 & 0.92 & 0.88 & 2.74 & 1.86 \\
\hline & & Female & 0.93 & 0.25 & 0.76 & 0.50 & 0.95 & 0.45 \\
\hline \multirow[t]{4}{*}{ Eif2ak3 mRNA expression (fold change) } & \multirow[t]{2}{*}{ Apoe $^{-/-} \mid \operatorname{tga} 8^{+/+}$} & Male & 0.80 & 0.07 & 0.84 & 0.60 & 0.96 & 0.36 \\
\hline & & Female & 1.00 & 0.10 & 1.03 & 0.81 & 1.18 & 0.37 \\
\hline & \multirow[t]{2}{*}{ Apoe $^{-1-} \mid \operatorname{tga} 8^{-1-}$} & Male & 0.71 & 0.10 & 0.67 & 0.53 & 0.95 & 0.42 \\
\hline & & Female & 0.86 & 0.06 & 0.85 & 0.79 & 1.02 & 0.23 \\
\hline \multirow[t]{4}{*}{ Ddit3 mRNA expression (fold change) } & \multirow[t]{2}{*}{ Apoe $^{-/-} \operatorname{ltga8^{+/+}}$} & Male & 0.89 & 0.13 & 0.87 & 0.57 & 1.23 & 0.66 \\
\hline & & Female & 1.00 & 0.12 & 1.06 & 0.75 & 1.22 & 0.47 \\
\hline & \multirow[t]{2}{*}{ Apoe $^{-1-} \operatorname{ltga8^{-1-}}$} & Male & 0.70 & 0.10 & 0.58 & 0.51 & 0.94 & 0.43 \\
\hline & & Female & 0.88 & 0.08 & 0.78 & 0.74 & 0.99 & 0.25 \\
\hline \multirow[t]{4}{*}{ Hspa5 mRNA expression (fold change) } & \multirow[t]{2}{*}{ Apoe $^{-/-} \mid \operatorname{tga} 8^{+/+}$} & Male & 0.92 & 0.13 & 0.88 & 0.63 & 1.25 & 0.62 \\
\hline & & Female & 1.00 & 0.14 & 0.88 & 0.78 & 1.28 & 0.5 \\
\hline & \multirow[t]{2}{*}{ Apoe $^{-1-} \mid \operatorname{tga} 8^{-1-}$} & Male & 0.79 & 0.06 & 0.75 & 0.66 & 0.99 & 0.33 \\
\hline & & Female & 0.81 & 0.08 & 0.79 & 0.66 & 0.98 & 0.32 \\
\hline \multirow[t]{4}{*}{ Vegfa mRNA expression (fold change) } & \multirow[t]{2}{*}{ Apoe $^{-/-} \operatorname{ltga8^{+/+}}$} & Male & 0.67 & 0.04 & 0.65 & 0.59 & 0.76 & 0.17 \\
\hline & & Female & 1.00 & 0.05 & 1.02 & 0.90 & 1.11 & 0.21 \\
\hline & Apoe $^{-/-} \mid \operatorname{tg} a 8^{-/-}$ & Male & 0.68 & 0.05 & 0.66 & 0.59 & 0.79 & 0.2 \\
\hline & & Female & 0.85 & 0.06 & 0.81 & 0.71 & 0.97 & 0.26 \\
\hline
\end{tabular}

$\# p<0.05$ vs Itga ${ }^{+/+}$of the same sex

${ }^{*} p<0.05$ vs male of the same genotype

also numerous studies which report considerably more pronounced atherosclerosis in males compared to females (reviewed in [18]). The reasons for these discrepant data are presently not clear, but might involve differences in the genetic background of experimental animals. In C57BL/6 mice, for example, significantly reduced HDL levels were found under an atherogenic diet in female animals [36]. In contrast, serum levels of HDL in our Apoe-deficient mice on the mixed genetic background $(\mathrm{C} 57 \mathrm{BL} / 6 \mathrm{x} 129 \mathrm{~Sv})$ were comparable between the sexes. Similar divergent observations were made with triglyceride levels in Apoe-deficient mice on the C57BL/ 6 or Ola129 genetic backgrounds [21]. Furthermore, in our study, Apoe-deficient animals were not exposed to 


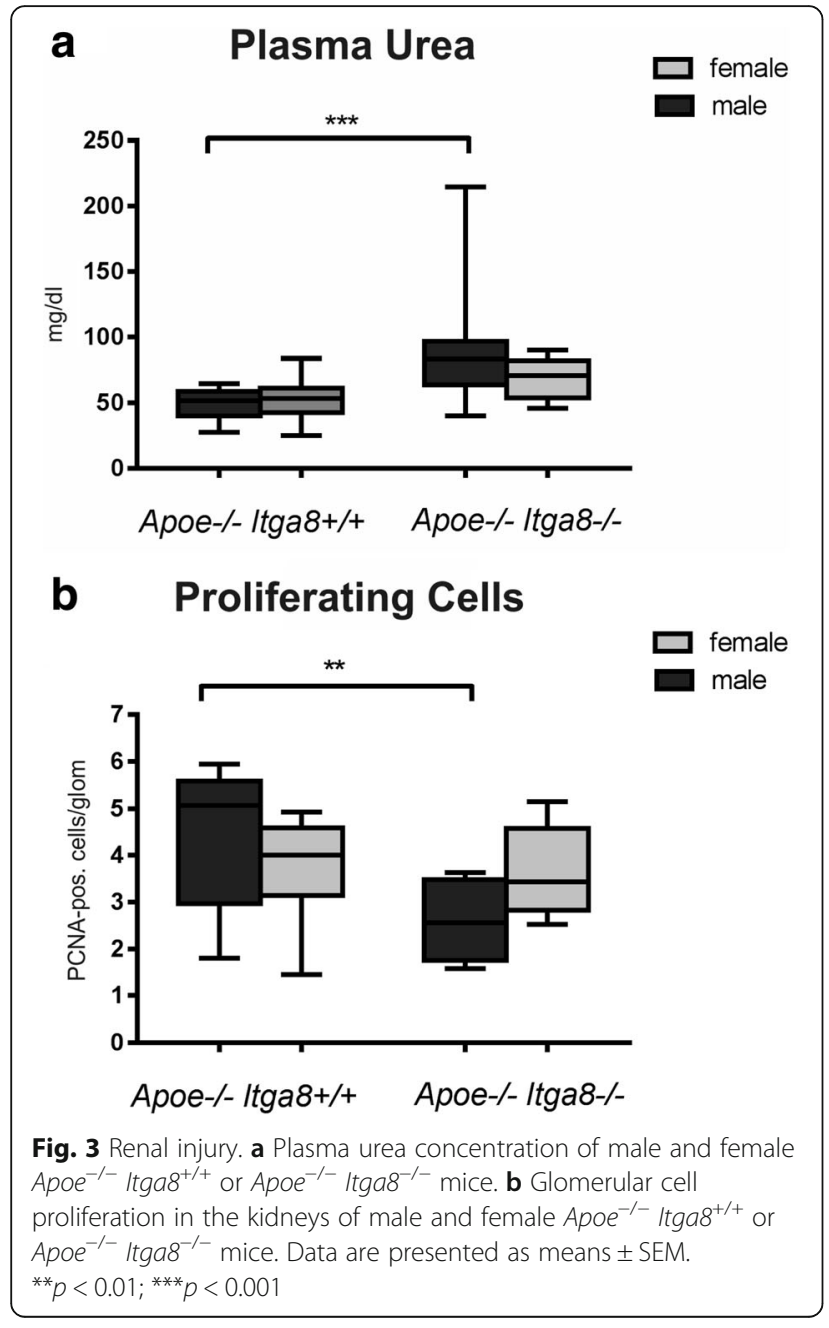

an atherogenic diet, which seems to be a relevant stimulus for HDL regulation in these mice [36]. Taken together, sex-dependent regulation of serum fat levels does not seem to be the underlying mechanism leading to more severe atherosclerosis in female Apoe-deficient mice in our study. Sex hormones may exert protective roles in the development of atherosclerosis. While it is widely accepted that estrogens have protective effects on the cardiovascular system [37], testosterone levels in the physiological range are also assumed to have protective effects [38]. In this context, the age-dependent decrease in testosterone levels and associated metabolic alterations are relevant pathogenetic factors for the development of atherosclerosis in men [39, 40]. Vasculoprotective effects of testosterone were also shown in animal studies. Thus, the less severe atherosclerotic changes in male Apoe-deficient mice compared to females might be caused by beneficial effects of testosterone.

Hyperlipidemia is associated with an elevated risk for the development of kidney disease [41, 42]. Numerous clinical and animal studies suggest that Apoe deficiency

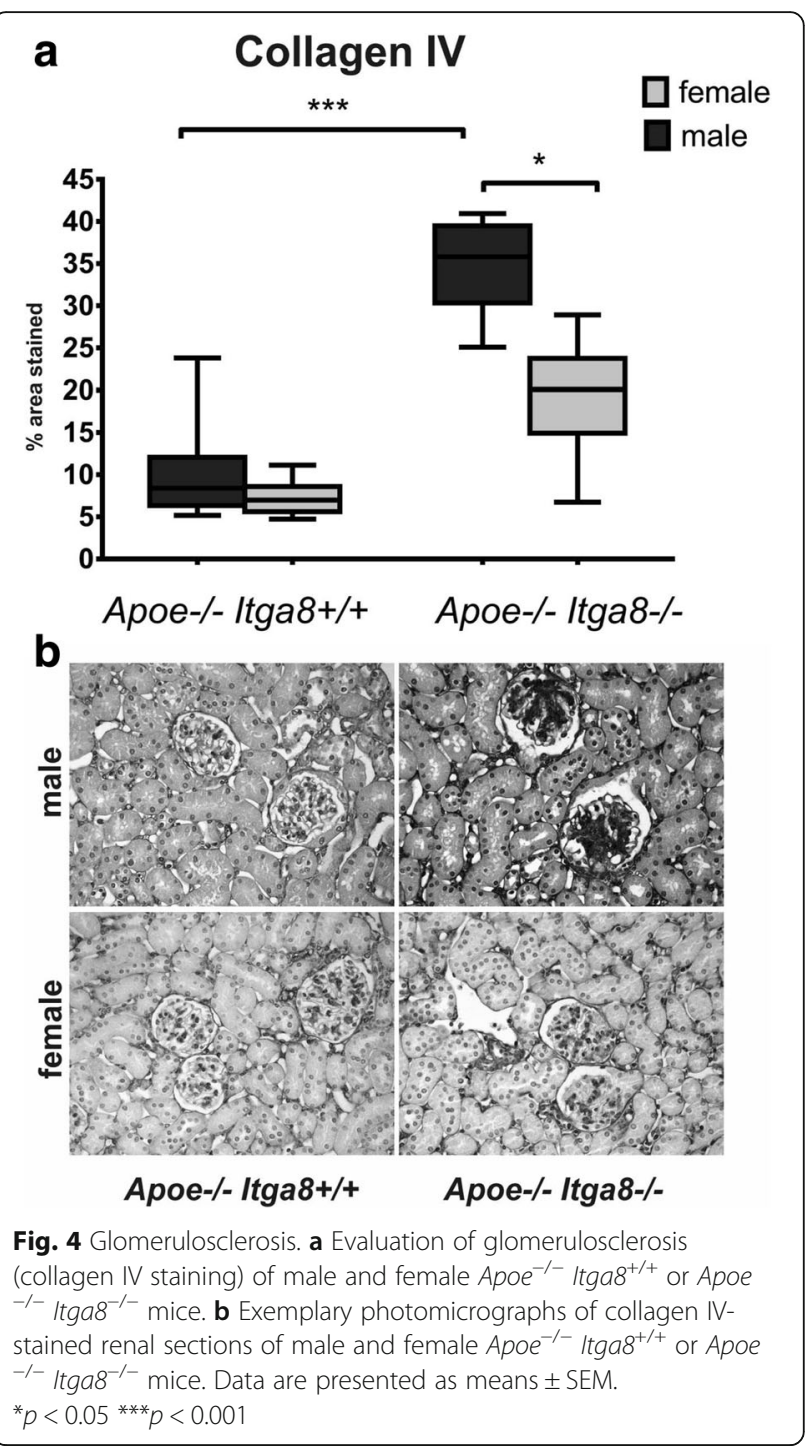

can be accompanied by renal disease $[4,43]$. In our model of Apoe deficiency, however, overt renal injury did not develop without an additional challenge, like the concomitant deficiency of Itga8 [5]. In male mice with an Apoe-Itga8 double deficiency $\left(\right.$ Apoe $^{-/-} \operatorname{Itga8}^{-/-}$), we detected marked glomerulosclerosis [5], which was clearly attenuated by the female sex, as shown in the present study. Different hormone levels in male and female mice might affect the susceptibility to develop renal injury, as some evidence exists that testosterone action in the kidney may contribute to glomerulosclerosis [44, 45].

ER stress response was shown to play a crucial role in the development of atherosclerosis and kidney disease $[46,47]$. The chaperone CHOP (synonym Ddit3) was found as a target to modulate the severity of atherosclerotic lesions in Apoe-deficient mice [48]. Moreover, sex differences in the induction of ER stress biomarker 


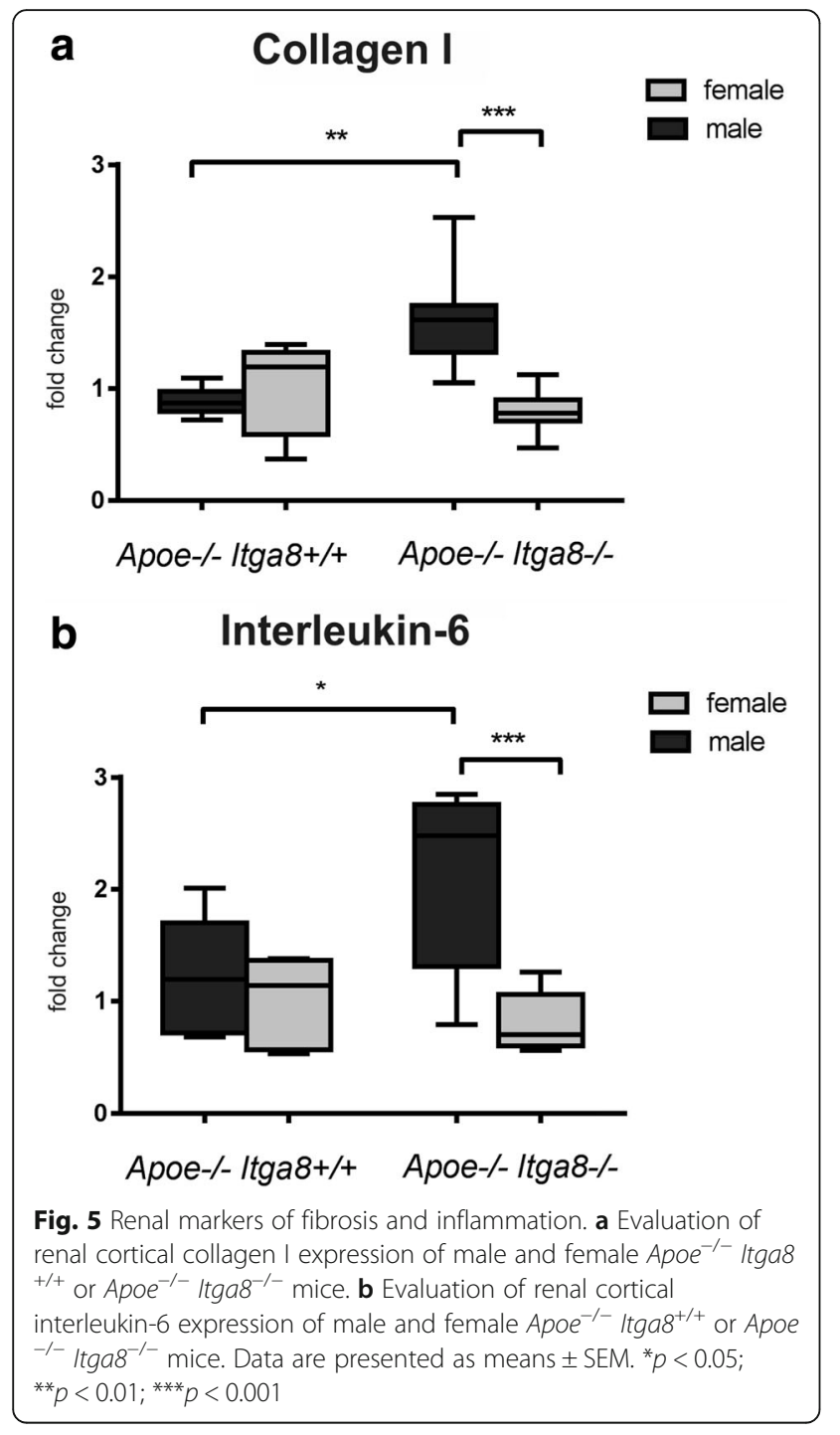

expression were detected in experimental hypertension [49]. Therefore, we tested the hypothesis that ER stress parameters might be differentially regulated in our male and female Apoe-Itga 8 double-deficient $\left(\right.$ Apoe $^{-/-}$Itga 8 $\left.{ }^{-1-}\right)$ mice. In our study, the expression patterns of the chaperones Ddit3, Eif2ak3, and Hspa 5 were comparable in males and females, arguing against a relevant role for ER stress in sex differences during the development of kidney damage in Apoe-Itga8 double-deficient $\left(\right.$ Apoe $^{-/-}$ Itga $8^{-/-}$) mice.

In a rat study of chronic renal disease, female rats were protected from the progression of renal injury by estrogen-stimulated Vegfa expression [50]. In contrast, VEGF seemed to be detrimental for atherosclerotic plaque progression [51]. We therefore tested Vegfa expression in our model. Vegfa expression was somewhat higher in female Apoe-deficient $\left(\right.$ Apoe $^{-/-}$Itga $\left.^{+/+}\right)$mice compared to males. However, Vegfa expression levels of

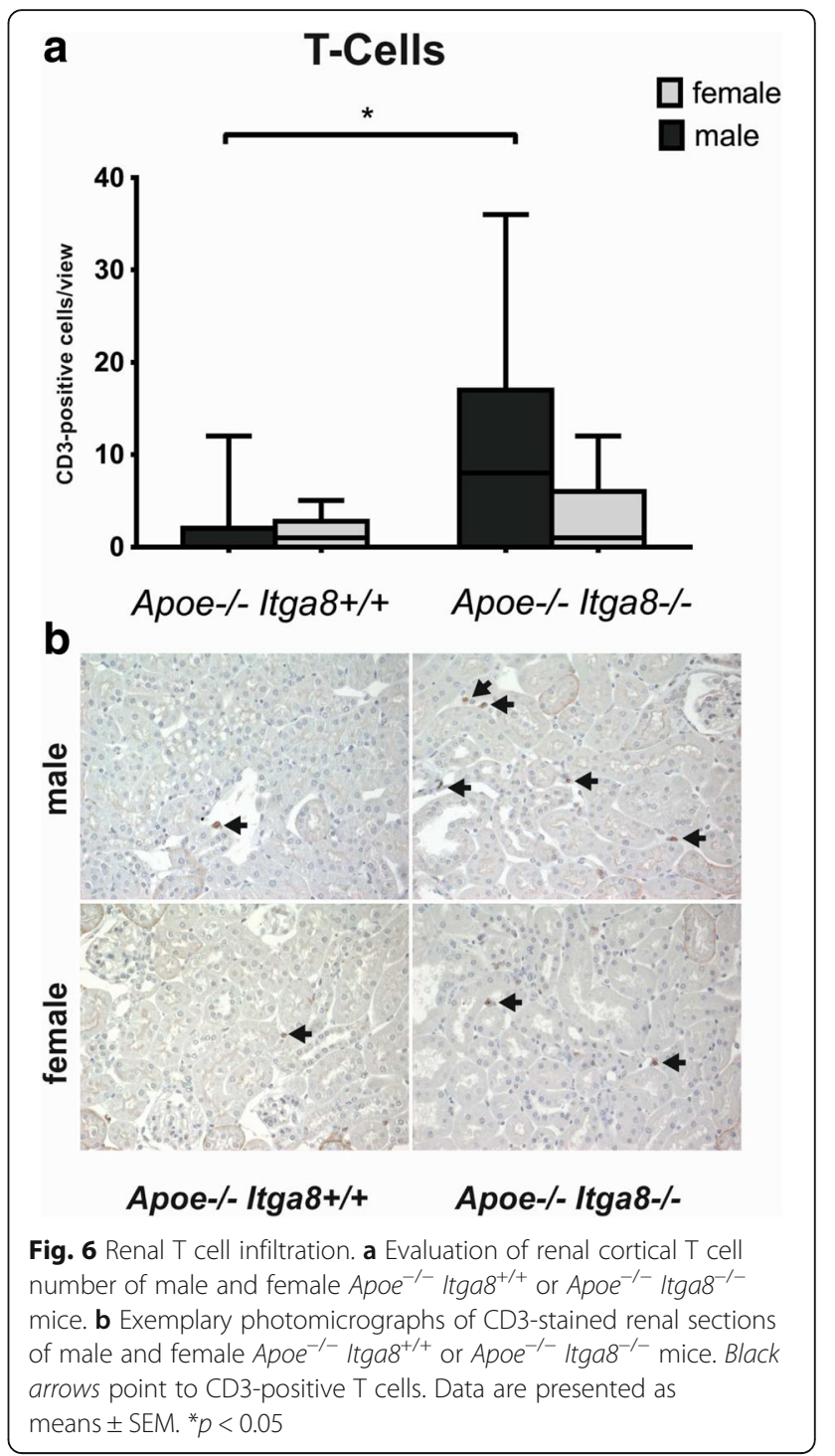

Apoe-Itga 8 double-deficient $\left(\right.$ Apoe $\left.^{-/-} \operatorname{Itga~}^{-/-}\right)$were not different between males and females and can therefore not explain the higher susceptibility for renal injury in male mice of this genotype.

Several studies detected sex differences in the inflammatory response during cardiovascular disease [52, 53]. Ji et al. showed a sex-dependent regulation of $\mathrm{T}$ cells and $\mathrm{T}$ cell-mediated functions in an animal model of hypertension with an induced activation of $\mathrm{T}$ cells in males [54]. T cells seem to have important functions in the development of atherosclerosis of Apoe-deficient mice. Laskowitz et al. showed an impaired $\mathrm{T}$ cellassociated immune response [55]. Robert et al. described a higher renal $\mathrm{T}$ cell infiltration rate in male animals after experimental kidney ischemia-reperfusion injury compared to females [56]. In our study, a significantly higher $\mathrm{T}$ cell infiltration of the kidney from male ApoeItga 8 double-deficient $\left(\right.$ Apoe $^{-/-}$Itga $\left.8^{-/-}\right)$animals 
compared to females was also detected. This notion is supported by concordantly altered expression patterns of the cytokines $\mathrm{Il6}$ and $\mathrm{Cxcl3}$, arguing for differences in the inflammatory response in male and female ApoeItga 8 double-deficient $\left(\right.$ Apoe $^{-/-}$Itga $\left.^{-/-}\right)$mice. These differences might contribute to the more severe renal injury in male mice compared to females.

In our experimental model, we observed higher osteopontin levels in female mice of both genotypes $\left(\right.$ Apoe $^{-/-}$ $\mathrm{Itga}^{+/+}$and $\mathrm{Apoe}^{-/-}$Itga $\left.^{-/-}\right)$compared to males. Osteopontin (Spp1) is known to be regulated by sex hormones: Estrogen can induce osteopontin expression [57], while testosterone is able to suppress it [58]. Osteopontin is a multifunctional protein contributing to the regulation of inflammation, atherosclerosis, and vascular calcification [59]. In accordance with our observations, osteopontin was described to be present in calcified vessels [60]. Whether osteopontin is beneficial or detrimental in atherosclerosis is controversial, but it seems that osteopontin contributes to the onset of aortic calcification, while it inhibits the progression of atherosclerosis [61]. Matsui et al. found that osteopontin deficiency attenuated atherosclerosis in female Apoe-deficient mice [62]. We therefore speculate that high levels of vascular osteopontin might contribute to the more severe atherosclerotic lesions detected in our female Apoedeficient mice $\left(\right.$ Apoe $^{-/-}$Itga $^{+/+}$and Apoe $^{-/-}$Itga $\left.^{-/-}\right)$. Although the action of osteopontin in the kidney is still somewhat controversial [63], several studies found renoprotective effects of osteopontin [64-66]. This might explain the protection from renal damage observed in our female Apoe-Itga8 double-deficient $\left(\mathrm{Apoe}^{-/-} \mathrm{Itga}^{-/-}\right)$mice.

\section{Conclusions}

Taken together, we observed that in the Apoe-deficient model of atherosclerosis, the female sex is a risk factor to develop more severe atherosclerotic lesions, although serum fat levels are not higher in females than in males. In contrast, female mice are protected from renal damage induced by the concomitant deficiency of Apoe and Itga8. These differences might be due to sex differences in the inflammatory response and/or osteopontin levels. Thus, sex affects vascular and renal injury not uniformly but in a differential manner. The reason for these differential outcomes is not clear by now, but our results suggest that there is more than one risk factor contributing to the development of vascular or renal lesions in our animal model of hyperlipidemia. The development of organ damage seems to be a result of an interplay of sex, genotype, serum lipids, and inflammatory mediators, which might affect organs differentially.

\section{Limitation}

In our study, we used mice on a mixed genetic background. Therefore, our data cannot readily be extrapolated to data that has been collected in similar studies performed with mice on a pure genetic background.

\section{Additional files}

\begin{abstract}
Additional file 1: Primer pairs used in the study. (DOCX 24 kb)
Additional file 2: Anatomical and metabolic parameters of mice without a deletion in Apoe (Apoe $e^{+/+}$Itga $8^{+/+}$or $A p o e^{++} /$tga $^{-/-}$). (DOCX $22 \mathrm{~kb}$ )

Additional file 3: Results from two-way ANOVA of markers of vascular and renal injury. (DOCX $19 \mathrm{~kb}$ )

Additional file 4: Atherosclerotic plaque formation in mice without a deficiency of Apoe. Exemplary en face preparations of aortae of male and female $A p o e^{+/+} /$tga $^{+/+}$or Apoe $e^{+/+}$Itga $8^{-/-}$mice, stained with Sudan IV (left) or unstained (right). One en face preparation of the aorta of an Apoe-deficient $\left(\right.$ Apoe $^{-/-}$Itga $8^{+/+}$) female mouse was stained for Sudan IV as a positive control. (PDF $257 \mathrm{~kb}$ )
\end{abstract}

Additional file 5: Osteopontin in the brachiocephalic trunk. Exemplary osteopontin-stained cross sections of the brachiocephalic trunk of male and female mice with a deficiency of Apoe. (PDF $303 \mathrm{~kb}$ )

Additional file 6: Vascular and renal changes in 7- and 9-month-old mice. (DOCX $25 \mathrm{~kb}$ )

Additional file 7: Osteopontin in the kidney. Exemplary photomicrographs of osteopontin-stained renal sections of male and female $A p o e^{-/-}$Itga $8^{+/+}$or Apoe $e^{-/-}$Itga ${ }^{-/-}$mice. (PDF $548 \mathrm{~kb}$ )

\section{Abbreviations}

Actb: Beta actin, gene; Apoe: Apolipoprotein E, gene; Apoe ${ }^{-/-}$: Apoe-deficient; CCl2: CC-chemokine ligand 2, gene; Col1a1: Collagen 1, gene;

CxCl3: Chemokine (C-X-C motif) ligand 3, gene; Ddit3: DNA-damage inducible transcript 3, gene; Eif2ak3: Eukaryotic translation initiation factor 2-alpha kinase 3, gene; Gapdh: Glyceraldehyde 3-phosphate dehydrogenase, gene; HDL: High-density lipoprotein; Hspa5: Heat shock protein family A (hsp70) member 5, gene; II6: Interleukin-6, gene; Itga8: Integrin alpha 8, gene; Itga8 ${ }^{-1-}$ : Itga8-deficient; LC-MS/MS: Liquid chromatography-tandem mass spectrometry; LDL: Low-density lipoprotein; PCNA: Proliferating cell nuclear antigen; Rn18s: $18 \mathrm{~S}$ rRNA, gene; SEM: Standard error of the mean; SPE-HPLCMS/MS: Solid-phase extraction-liquid chromatography-tandem mass spectrometry; Spp 1: Secreted phosphoprotein 1, gene; Vegfa: Vascular endothelial growth factor, gene

\section{Acknowledgements}

The authors thank Miroslava Kupraszewicz-Hutzler and Rainer Wachtveitl for excellent technical assistance. The authors further thank Sabrina Sarajy-Fahlbusch for revising the manuscript for the English language. Part of the experiments and analysis of data was performed by Maurizio Canu in fulfillment of the requirements for obtaining the degree "Dr. med." at the Friedrich-Alexander University of Erlangen-Nürnberg, Dept. of Pediatrics and Adolescent Medicine, Germany.

\section{Funding}

This study was supported by a grant from the Deutsche

Forschungsgemeinschaft, Bonn, Germany (SFB 423, Project A2) to AH; the "Interdisziplinaeres Zentrum fuer Klinische Forschung" at the University Hospital of Erlangen-Nuernberg, funded by the "Bundesministerium fuer Bildung und Forschung" (01 KS 0002) to AH and KFH; and an ELAN grant from the University of Erlangen-Nuernberg to $\mathrm{AH}$.

\section{Availability of data and materials}

The datasets analyzed during the current study are available from the corresponding author on reasonable request.

\section{Authors' contributions}

$\mathrm{IM}$ and $\mathrm{KFH}$ participated in the experimental design, data analysis, and writing of the manuscript. MC, NC, GV, and FBF participated in the statistical analyses and planned, conducted, and interpreted the experiments. WR participated in the experimental design and writing of the manuscript. $\mathrm{AH}$ and CMC participated in the experimental design, statistical analysis, and 
writing of the manuscript. MR conducted experiments and participated in the data analysis. All authors read and approved the final manuscript.

\section{Competing interests}

The authors declare that they have no competing interests.

\section{Consent for publication}

Not applicable

\section{Ethics approval}

All procedures performed on animals were approved by the local government authorities (Regierung von Mittelfranken, AZ No. 621-2531.3110/02) and were done in compliance with the DIRECTIVE 2010/63/EU of the European Parliament.

\section{Publisher's Note}

Springer Nature remains neutral with regard to jurisdictional claims in published maps and institutional affiliations.

\section{Author details}

'Department of Pediatrics and Adolescent Medicine, University Hospital of Erlangen-Nuernberg, Loschgestrasse 15, 91054 Erlangen, Germany. ${ }^{2}$ Department of Nephrology and Hypertension, University Hospital of Erlangen-Nuernberg, Erlangen, Germany.

\section{Received: 1 February 2017 Accepted: 23 May 2017} Published online: 30 May 2017

\section{References}

1. Meir KS, Leitersdorf E. Atherosclerosis in the apolipoprotein-E-deficient mouse: a decade of progress. Arterioscler Thromb Vasc Biol. 2004;24(6):1006-14.

2. Knowles JW, Maeda N. Genetic modifiers of atherosclerosis in mice. Arterioscler Thromb Vasc Biol. 2000;20(11):2336-45

3. Balarini $\mathrm{CM}$, et al. Hypercholesterolemia promotes early renal dysfunction in apolipoprotein E-deficient mice. Lipids Health Dis. 2011;10:220.

4. Wen $\mathrm{M}$, et al. Renal injury in apolipoprotein E-deficient mice. Lab Invest. 2002;82(8):999-1006

5. Menendez-Castro $C$, et al. Under-expression of alpha8 integrin aggravates experimental atherosclerosis. J Pathol. 2015;236(1):5-16.

6. Hartner A, et al. Lack of \{alpha\}8-integrin aggravates podocyte injury in experimental diabetic nephropathy. Am J Physiol Renal Physiol. 2010;299(5): F1151-7.

7. Schnapp LM, et al. Sequence and tissue distribution of the human integrin alpha 8 subunit: a beta 1-associated alpha subunit expressed in smooth muscle cells. J Cell Sci. 1995;108(Pt 2):537-44.

8. Zargham $\mathrm{R}$, Thibault $\mathrm{G}$. alpha8beta1 Integrin expression in the rat carotid artery: involvement in smooth muscle cell migration and neointima formation. Cardiovasc Res. 2005;65(4):813-22.

9. Hartner $\mathrm{A}$, et al. The alpha8 integrin chain affords mechanical stability to the glomerular capillary tuft in hypertensive glomerular disease. Am J Pathol. 2002;160(3):861-7.

10. Tian $Y$, et al. Effects of gender on gene expression in the blood of ischemic stroke patients. J Cereb Blood Flow Metab. 2012;32(5):780-91.

11. Sofia RR, et al. Gender-based differences in cardiac remodeling and ILK expression after myocardial infarction. Arq Bras Cardiol. 2014;103(2):124-30.

12. Cobo G, et al. Sex and gender differences in chronic kidney disease: progression to end-stage renal disease and haemodialysis. Clin Sci (Lond). 2016:130(14):1147-63.

13. Dasinger $\mathrm{JH}$, Alexander BT. Gender differences in developmental programming of cardiovascular diseases. Clin Sci (Lond). 2016:130(5):337-48.

14. Maranon R, Reckelhoff JF. Sex and gender differences in control of blood pressure. Clin Sci (Lond). 2013;125(7):311-8.

15. Meyrelles SS, et al. Endothelial dysfunction in the apolipoprotein E-deficient mouse: insights into the influence of diet, gender and aging. Lipids Health Dis. 2011:10:211.

16. Tangirala RK, Rubin EM, Palinski W. Quantitation of atherosclerosis in murine models: correlation between lesions in the aortic origin and in the entire aorta, and differences in the extent of lesions between sexes in LDL receptor-deficient and apolipoprotein E-deficient mice. J Lipid Res. 1995; 36(11):2320-8.
17. Bourassa PA, et al. Estrogen reduces atherosclerotic lesion development in apolipoprotein E-deficient mice. Proc Natl Acad Sci U S A. 1996;93(19): 10022-7.

18. Pereira TM, et al. Cardiac and vascular changes in elderly atherosclerotic mice: the influence of gender. Lipids Health Dis. 2010;9:87.

19. Carneiro SS, et al. Endogenous female sex hormones delay the development of renal dysfunction in apolipoprotein E-deficient mice. Lipids Health Dis. 2014;13:176.

20. Smith DD, et al. Increased aortic atherosclerotic plaque development in female apolipoprotein E-null mice is associated with elevated thromboxane A2 and decreased prostacyclin production. J Physiol Pharmacol. 2010;61(3):309-16.

21. Surra JC, et al. Sex as a profound modifier of atherosclerotic lesion development in apolipoprotein E-deficient mice with different genetic backgrounds. J Atheroscler Thromb. 2010;17(7):712-21.

22. Doublier $\mathrm{S}$, et al. Testosterone and 17beta-estradiol have opposite effects on podocyte apoptosis that precedes glomerulosclerosis in female estrogen receptor knockout mice. Kidney Int. 2011;79(4):404-13.

23. Elliot SJ, et al. Gender-specific effects of endogenous testosterone: female alpha-estrogen receptor-deficient C57BI/6J mice develop glomerulosclerosis. Kidney Int. 2007;72(4):464-72

24. Zeier $\mathrm{M}$, et al. Effects of testosterone on glomerular growth after uninephrectomy. Nephrol Dial Transplant. 1998;13(9):2234-40.

25. Reddick RL, Zhang SH, Maeda N. Atherosclerosis in mice lacking apo E. Evaluation of lesional development and progression. Arterioscler Thromb. 1994;14(1):141-7.

26. Jacobi J, et al. Dimethylarginine dimethylaminohydrolase overexpression ameliorates atherosclerosis in apolipoprotein E-deficient mice by lowering asymmetric dimethylarginine. Am J Pathol. 2010;176(5):2559-70.

27. Menendez-Castro C, et al. Intrauterine growth restriction promotes vascular remodelling following carotid artery ligation in rats. Clin Sci (Lond). 2012; 123(7):437-44

28. Hartner A, et al. Glomerular osteopontin expression and macrophage infiltration in glomerulosclerosis of DOCA-salt rats. Am J Kidney Dis. 2001; 38(1):153-64.

29. Friedewald WT, Levy RI, Fredrickson DS. Estimation of the concentration of low-density lipoprotein cholesterol in plasma, without use of the preparative ultracentrifuge. Clin Chem. 1972;18(6):499-502.

30. Rauh $\mathrm{M}$, et al. Automated, fast and sensitive quantification of 17 alphahydroxy-progesterone, androstenedione and testosterone by tandem mass spectrometry with on-line extraction. Steroids. 2006;71(6):450-8.

31. Kagari T, Doi H, Shimozato T. The importance of IL-1 beta and TNF-alpha, and the noninvolvement of $\mathrm{IL}-6$, in the development of monoclonal antibody-induced arthritis. J Immunol. 2002;169(3):1459-66.

32. Group EUCCS, et al. Gender in cardiovascular diseases: impact on clinical manifestations, management, and outcomes. Eur Heart J. 2016;37(1):24-34

33. Thomas CM, Smart EJ. Gender as a regulator of atherosclerosis in murine models. Curr Drug Targets. 2007:8(11):1172-80.

34. Mathur $P$, et al. Gender-related differences in atherosclerosis. Cardiovasc Drugs Ther. 2015;29(4):319-27.

35. Caligiuri $\mathrm{G}$, et al. Effects of sex and age on atherosclerosis and autoimmunity in apoE-deficient mice. Atherosclerosis. 1999;145(2):301-8.

36. Paigen $B$, et al. Comparison of atherosclerotic lesions and $\mathrm{HDL}$-lipid levels in male, female, and testosterone-treated female mice from strains C57BL/6, BALB/C, and C3H. Atherosclerosis. 1987;64(2-3):215-21.

37. Perez-Lopez FR, et al. Gender differences in cardiovascular disease: hormonal and biochemical influences. Reprod Sci. 2010;17(6):511-31.

38. Snyder PJ, et al. Effect of transdermal testosterone treatment on serum lipid and apolipoprotein levels in men more than 65 years of age. Am J Med. 2001;111(4):255-60.

39. Harman SM, et al. Longitudinal effects of aging on serum total and free testosterone levels in healthy men. Baltimore Longitudinal Study of Aging. J Clin Endocrinol Metab. 2001:86(2):724-31.

40. Barrett-Connor E, Goodman-Gruen D, Patay B. Endogenous sex hormones and cognitive function in older men. J Clin Endocrinol Metab. 1999:84(10):3681-5.

41. Sacks FM, et al. Association between plasma triglycerides and high-density lipoprotein cholesterol and microvascular kidney disease and retinopathy in type 2 diabetes mellitus: a global case-control study in 13 countries. Circulation. 2014:129(9):999-1008.

42. Battisti WP, Palmisano J, Keane WE. Dyslipidemia in patients with type 2 diabetes, relationships between lipids, kidney disease and cardiovascular disease. Clin Chem Lab Med. 2003;41(9):1174-81. 
43. Liberopoulos E, et al. Apolipoprotein E polymorphism in northwestern Greece: frequency and effect on lipid parameters. Ann Clin Lab Sci. 2004; 34(3):347-54.

44. Herlitz LC, et al. Development of focal segmental glomerulosclerosis after anabolic steroid abuse. J Am Soc Nephrol. 2010;21(1):163-72.

45. Liu B, Ely D. Testosterone increases: sodium reabsorption, blood pressure, and renal pathology in female spontaneously hypertensive rats on a high sodium diet. Adv Pharmacol Sci. 2011;2011:817835.

46. Hotamisligil GS. Endoplasmic reticulum stress and atherosclerosis. Nat Med 2010;16(4):396-9.

47. Taniguchi M, Yoshida $\mathrm{H}$. Endoplasmic reticulum stress in kidney function and disease. Curr Opin Nephrol Hypertens. 2015;24(4):345-50.

48. Thorp E, et al. Reduced apoptosis and plaque necrosis in advanced atherosclerotic lesions of Apoe-/- and Ldlr-/- mice lacking CHOP. Cell Metab. 2009:9(5):474-81.

49. Dai SY, et al. Endoplasmic reticulum stress in the brain subfornical organ contributes to sex differences in angiotensin-dependent hypertension in rats. Acta Physiol. 2016;217(1):33-44.

50. Kang DH, et al. The impact of gender on progression of renal disease-potential role of estrogen-mediated vascular endothelial growth factor regulation and vascular protection. Am J Pathol. 2004;164(2):679-88.

51. Celletti FL, et al. Vascular endothelial growth factor enhances atherosclerotic plaque progression. Nat Med. 2001;7(4):425-9.

52. Fairweather D. Sex differences in inflammation during atherosclerosis. Clin Med Insights Cardiol. 2014;8 Suppl 3:49-59.

53. Regitz-Zagrosek $\vee$, Kararigas G. Mechanistic pathways of sex differences in cardiovascular disease. Physiol Rev. 2017;97(1):1-37.

54. Ji H, et al. Sex-specific T cell regulation of angiotensin II-dependent hypertension RR. Hypertension. 2014;64(3):573-82.

55. Laskowitz DT, et al. Altered immune responses in apolipoprotein E-deficient mice. J Lipid Res. 2000;41(4):613-20.

56. Robert R, et al. Gender difference and sex hormone production in rodent renal ischemia reperfusion injury and repair. J Inflamm (Lond). 2011:8:14.

57. Craig AM, Denhardt DT. The murine gene encoding secreted phosphoprotein 1 (osteopontin): promoter structure, activity, and induction in vivo by estrogen and progesterone. Gene. 1991;100:163-71.

58. Yagisawa $\mathrm{T}$, et al. The influence of sex hormones on renal osteopontin expression and urinary constituents in experimental urolithiasis. J Urol. 2001; 166(3):1078-82.

59. Cho H-J, Cho H-J, Kim H-S. Osteopontin: a multifunctional protein at the crossroads of inflammation, atherosclerosis, and vascular calcification. Current Atherosclerosis Reports. 2009;11(3):206-13.

60. Evrard S, et al. Vascular calcification: from pathophysiology to biomarkers. Clin Chim Acta. 2015:438:401-14.

61. Shao JS, et al. Vascular calcification and aortic fibrosis: a bifunctional role for osteopontin in diabetic arteriosclerosis. Arterioscler Thromb Vasc Biol. 2011; 31(8):1821-U279

62. Matsui $Y$, et al. Osteopontin deficiency attenuates atherosclerosis in female apolipoprotein E-deficient mice. Arterioscler Thromb Vasc Biol. 2003;23(6): 1029-34.

63. Xie YS, et al. Expression, roles, receptors, and regulation of osteopontin in the kidney. Kidney Int. 2001;60(5):1645-57.

64. Endlich $\mathrm{N}$, et al. Analysis of differential gene expression in stretched podocytes: osteopontin enhances adaptation of podocytes to mechanical stress. Faseb J. 2002;16(11):1850.

65. Schordan S, et al. OPN deficiency results in severe glomerulosclerosis in uninephrectomized mice. Am J Physiol Ren Physiol. 2013;304(12):F1458-70.

66. Xie $Y$, et al. Expression of osteopontin in gentamicin-induced acute tubular necrosis and its recovery process. Kidney Int. 2001:59(3):959-74.

\section{Submit your next manuscript to BioMed Central and we will help you at every step:}

- We accept pre-submission inquiries

- Our selector tool helps you to find the most relevant journal

- We provide round the clock customer support

- Convenient online submission

- Thorough peer review

- Inclusion in PubMed and all major indexing services

- Maximum visibility for your research

Submit your manuscript at www.biomedcentral.com/submit
) Biomed Central 